\section{State of the art in the use of bioceramics to elaborate 3D structures using robocasting}

Juliana Kelmy Macário Barboza Daguano ${ }^{1,2^{*} ;}$ Claudinei dos Santos; Manuel Fellipe Rodrigues Pais Alves4; Jorge Vicente Lopes da Silva2; Marina Trevelin Souzas; Maria Helena Figueira Vaz Fernandes ${ }^{6}$

"Corresponding author: E-mail address:julliana.daguano@ufabc.edu.br

Abstract: Robocasting, also known as Direct Ink Writing, is an Additive Manufacturing (AM) technique based on the direct extrusion of colloidal systems consisting of computer-controlled layer-by-layer deposition of a highly concentrated suspension (ceramic paste) through a nozzle into which this suspension is extruded. This paper presents an overview of the contributions and challenges in developing
three-dimensional (3D) ceramic biomaterials by this printing method. State-of-art in different bioceramics as Alumina, Zirconia, Calcium Phosphates, Glass/Glass-ceramics, and composites is presented and discussed regarding their applications and biological behavior in a survey comprising from the production of customized dental prosthesis to biofabricating 3D human tissues. Although robocasting represents a disruption in manufacturing porous structures, such as scaffolds for Tissue Engineering (TE), many drawbacks still remain to overcome and although widely disseminated this technique is far from allowing the obtainment of dense parts. Thus, strategies for manufacturing densified bioceramics are presented aiming at expanding the possibilities of this AM technique. The advantages and disadvantages and also future perspectives of applying robocasting in bioceramic processing are also explored.

Keywords: Additive Manufacturing (AM); Direct Ink Writing (DIW); Robocasting; Bioceramics; Challenges; Perspectives.
Introduction casting

By definition, Biomaterials are nonviable materials, natural or synthetic, that are useful towards the repair or even replacement of damaged terial with the host tissue can occur at different levels, from a minimum response (inert biomaterial), to an intimate interaction with the human
cells, sometimes replacing a component of the body or even carrying out their functions (bioactive or resorbable biomaterials). ${ }^{\prime}$ As soon as scientists and engineers understood that it was possible to modulate he biocompatibility of materials for biomedical applications, novel and advanced manufacturing techniques were explored. Those processes aimed to produce multicomponent structures otherwise difficult to obtain after implantation. Within s a solution Cesarano patented and developed the technique, that consists in a computer-controlled extrusion of a viscous ceramic suspension with a high solid loading through a small orifice creating filaments that are placed in a layer-by-layer deposition process. ${ }^{2}$ Figure 1 shows a schematic diagram illustrating this technique for obtaining of inert ceramic based on $\mathrm{ZrO}_{2}-\mathrm{Y}_{2} \mathrm{O}_{3}(\mathrm{Y}-\mathrm{TZP})$.

Universidade Federal do ABC, Grupo de Pesquisa em Biomateriais (UFABC-GPBiomat), Alameda da Universidade, s/n, Anchieta, São Bernard do Campo (SP), Brazil.

Centro de Tecnologia da Informação - Renato Archer, Núcleo de Tecnologias Tridimensionais (CTI-NT3D), Dom Pedro I Highway (SP-65), Km 43,6 - Amarais - Techno Park, Campinas (SP), Braz

3Universidade do Estado do Rio de Janeiro, Faculdade de Tecnologia de Resende (UERJ-FAT), Rodovia Presidente Dutra, $\mathrm{km} 298$, Polo Industrial Resende (RJ), Brazil

4Universidade de São Paulo, Escola de Engenharia de Lorena (USP-EEL-DEMAR), Pólo Urbo-Industrial, Gleba Al-6, s/n, Lorena (SP), Brazil.
sUniversidade Federal de São Carlos, Laboratório de Materiais Vítreos (UFSCar-LaMaV) Rodovia Washington Luís km 235, São Carlos SP), Brat. University of Aveiro, Aveiro Institute of Materials (CICECO-UA), Campus Universitário de Santiago, 3810-193 Aveiro, Portugal.

Received 09 January 2019; Accepted 20 February 2019; Available online 25 February 2019

(his suspension (or colloidal system) must demonstrate a suitable dilatant behavior when extruded in air, and following a computer-aided esign model to form the 3D structures. 3 Unlike other AM techniques, $40 \%(\mathrm{~V} / \mathrm{v}))$ - which may lead to sudden outgassing and crack formation due to excessive shrinkage of the structure ${ }^{4}$ - in robocasting process, As $(v /)$ and dispersants/binders less than $3 \%(v / N)$. dditives and a subsequent sintering process to densify the structures. density (up to $60 \%$ ) which allows almost complete densification ureen intering, achieving a sintered strut density near $95 \%, 6,7,8 \mathrm{~A}$ recent study scaffolds with the aim of getting the on-demand scaffold fabrication close Wards the clinical practice. The rapid and reactive pressure-less sinteast heating rates in the order of $100^{\circ} \mathrm{C} / \mathrm{min}$.

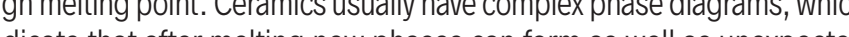

Technical Approaches - Additive Manufacturing and Robousing conventional routes, reduce cost and also improve performance

Ceramic robocasting is a direct AM technology, also named as Direct
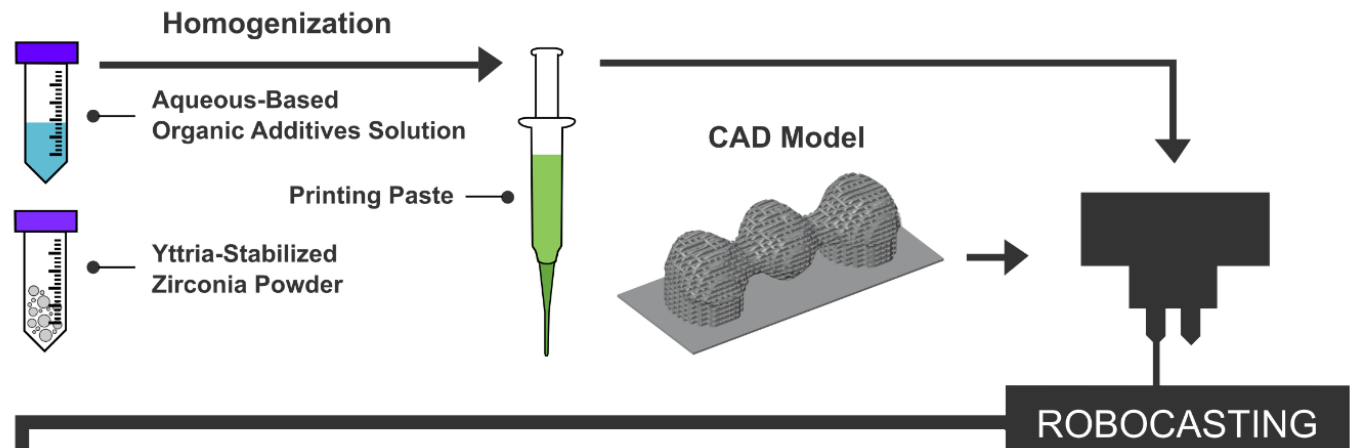

Layer-By-Layer Deposition Deposition Material (FDM), that usually involve binder-rich contents (above en body needs to undergo al aoninding process to bess, the resultan

Robocasting appears as a new tool to process bioceramics since this is notoriously dificult material to be processed. Firstly, due to its inherent 
(SiC), ${ }_{17,25}$ silicon nitride $\left(\mathrm{Si}_{3} \mathrm{~N}_{4}\right),{ }^{7}, 26 \mathrm{Y}$ Ytrium-stabilized zirconia $\left(\mathrm{ZrO}_{2} / \mathrm{Y}_{2} \mathrm{O}_{3}\right),{ }^{8}$ toughness. Various microstructural features contribute to the toughness and some bioactive glasses. $27,2,2,29$ Most of the reported works include of nacre, including mineral bridges, nano-asperities, and waviness of the rheological studies that allow the formulation of the ideal compositions consitiuent platelets. In this sense, it would be possible to replicate natura of ceramic masses and their respective optimized suspensions aiming st at particular porosity and mechanical performance of the sintered parts. Another challenge is related to mechanical properties of robocasted proposed to ripen mechanical properties of robocast bioceramic scaffolds could be to combine the ceramic with a polymeric material. The fabrication of hybrid polymer/ceramic porous scaffolds with core/shell struts thus, appears as an interesting possibility. This strategy provides enhanced toughness without affecting, in principle, the bioactivity of the scaffold surfaces or the interconnected porosity required for bone tissue regeneration. ${ }^{30}$ Another possibility is creating $3 \mathrm{D}$ Printing Bioinspired ceramic composites, using the biomimetic concept. A classic example is structures and build highly mineralized materials that retain strength while

Bioceramics for $3 \mathrm{D}$ printing using the Robocasting technique Due to their unique properties, bioceramics play a privileged role wiperiod of $2019-2024$ This is a motivation for a fast progress in bioceramic robocasting technology, and to keep up with the growth of the market.

or a better understanding of the state-of-art of robocasting, the and (in fully dense monolithic bioceramics, as schematically distinguished in Figure 2 .

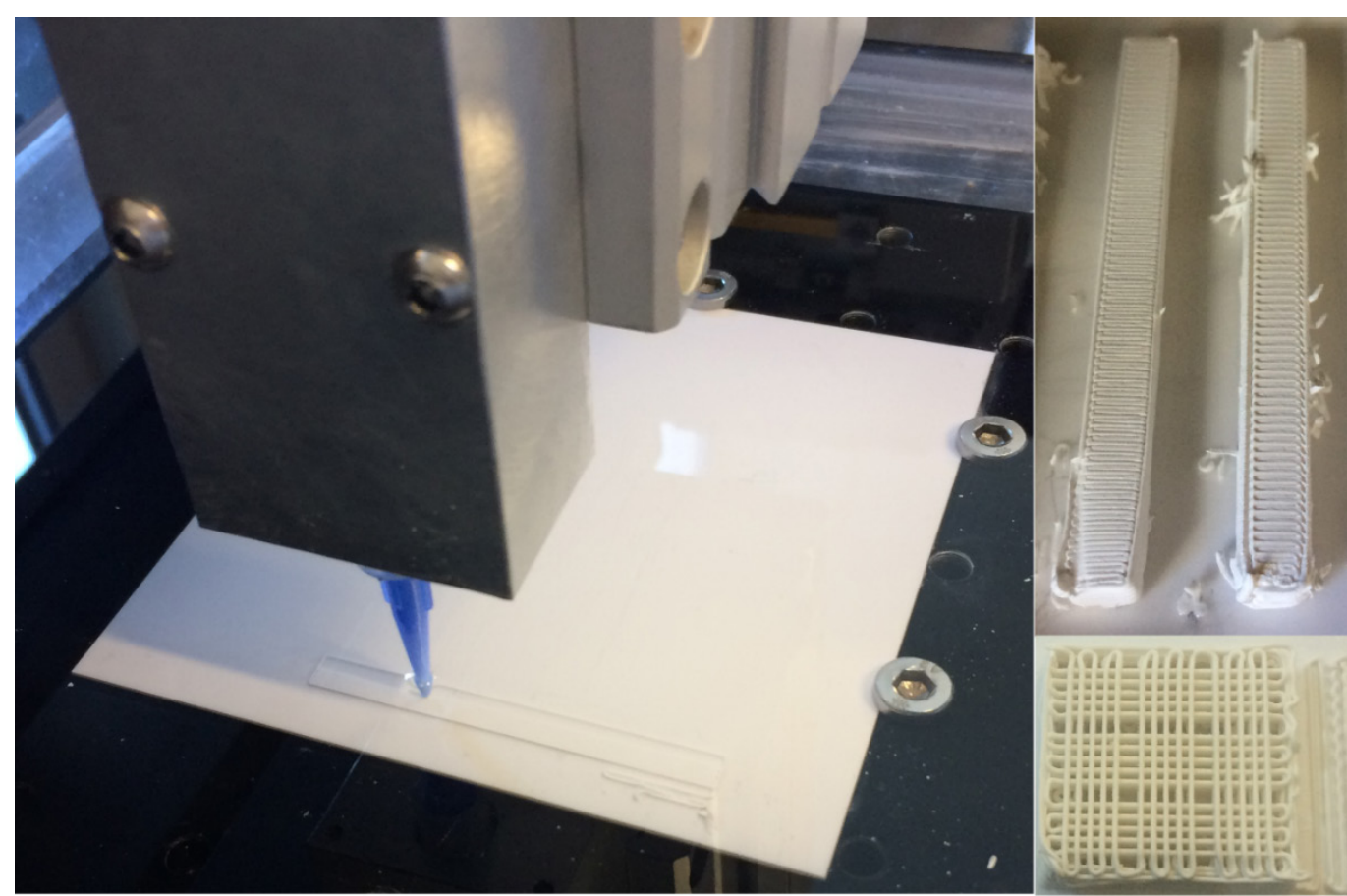

Figure 2 - Bioceramics fabricated by robocasting: (top right hand corner) fully dense monolithic parts, (bottom right hand corner) porous structures.

Porous Bioceramics

TE is a multidisciplinary research field that began in 1980's and combines engineering and life sciences in order to develop new methods for issue replacement with improved functionality. $\mathrm{A}$ A prime step in TE is the development of complex 3D shapes with tailored external geometries, pore volue Dealo ds are mainly designed to be a timporary implant, acting as a during/fter the healing process, so that the seeded cells can grow and proliferate to regenerate into a new tissue. .7,3,3, $^{3}$

Currently, most of the studies have used 3 D printing as a tool to make scaffolds for TE. Therefore, the microstructure features, I.e., interconnected porosity, pore size distribution, and filament aspects, are crucial factors to assure mechanical properties similar to those of the tissue and appropriate biocompatibility.

Some aspects of bioceramic ink parameters, such as ink chemistry processing additive (dispersant, binder, gelation agent), solids loading, powder reactivity, ceramic particle size, and distribution, must be understhere is a strong correlation between particle size distribution and the force needed to extrude ceramic loaded inks, such that a wide particle distribution allows the formulation of higher particle loaded inks. Nommeots-Nomm et al. described how wide distributions allow for intimate packing of the particles within the ink, resulting in denser filaments post sintering. Also, they suggested that Pluronic F-127, a water soluble block co-polymer surfactant with thermally reversing rheological behaviour, consisting of poly (ethylene oxide)-poly(propylene oxide)-poly(ethylen oxide) tri-blocks (PEO-PPO-PEO), can be used as a universal binder." Eqtsesadi et al. have suggested a simple recipe for robocasting 3D scaffolBions were successfully prepared using $1 \%$ t carboxymethy (CMC-250MW) as additive, tuning the rheological properties of the inks to meet the stringent requirements of robocasting. Another information is that an incomplete surface allowing bridging flocculation to occur is the key to obtain highly performing inks. ${ }^{22}$ Recently, Koski et al. proposed natural polymer binder system in ceramic composite scaffolds, throug h the utilization of naturally sourced gelatinized starch with hydroxyapatite (HA), in order to obtain green parts without the need of crosslinking or

post processing. 43
Scaffolds produced by robocasting generally possess better mechanical properties compared to those produced by indirect AM tech-

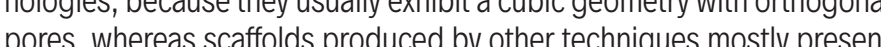
a cylindrical geometry with orthogonal or radial pores. The difference in strength can reach one order of magnitude. Scaffold struts produced by robocasting can be almost dense after sintering thus improving their mechanical properties. 4,45

Marques et al. reported the development of 3D porous calcium phosphate scaffolds by robocasting from biphasic (HA/ $\beta-\mathrm{TCP} \approx 1.5$ ) powders, undoped and co-doped with Sr and Ag, where the ceramic slurry content was around $50 \%(\mathrm{~V} / \mathrm{V})$. After sintering at $1100^{\circ} \mathrm{C}$, scaffolds with different pore sizes and rod average diameter of $410 \mathrm{~mm}$ were obtained. The compressive strength was comparable to or even higher than that of cancellous bone. Srand Ag enhanced he mechanical strength of scaffolds, Escherichia coli, and did not induce any cytotoxic effects on human MG-63 cells. Furthermore the ${ }^{2}$-doped powder was more effective in inducing pre-osteoblastic proliferation 46

To meet the requirements of a 3D scaffold, in vitro and in vivo tests are key steps for the development of new suitable biomaterials. In the following tables, we present a concise review on the in vitro and in vivo assays performed with robocasted bioceramics and biocomposite scaffolds and their outcomes and relevance to the field. There is a vast iterature exploring the mechanical behavior of $3 \mathrm{D}$ bioactive glass scaffolds manu- factured by the robocasting technique, but the literature regarding the interaction of cells with bioceramic scaffolds obtained by this processing method is fairly scarce. Generally, researchers focus on constructing hybrid materials and biocomposites aiming the optimization of the process. Some interesting studies on cell viability and proliferation when in contact with ocast bioceramics and biocomposites are presented in Table 1.

Regarding in vivo tests, up to this date, the five most relevant studies using bioglasses robocast scaffolds were conducted by Liu etal in 2013,3047 Deliormanli at in 2014,48 Pahaman etal in $2015^{49}$ and Lin l. in $2016 .{ }^{50} \mathrm{As}$ to other bioceramics several studies are reported and the int 20.0 


\begin{tabular}{|c|c|c|c|c|c|c|c|c|}
\hline Authors & Material Tested & Scaffold Characteristic & Porosity & In Vitro Test & Cell Line & Time & Outcomes & Ref \\
\hline Chung-Hun et al. & $\begin{array}{l}\text { Sol-gel bioactive glass (70SiOO }- \\
25 \mathrm{CaO}-5 \mathrm{P}_{2} \mathrm{O}_{5} \text { )and } \mathrm{PCL}\end{array}$ & $\begin{array}{l}\text { Degradable macro-channeled sca- } \\
\text { ffolds }\end{array}$ & $\begin{array}{l}\text { Pore size of } 500 \times 500 \\
\mu \mathrm{m}\end{array}$ & $\begin{array}{l}\text { MTT assays in static and dynamic } \\
\text { conditions }\end{array}$ & hASCS & Up to 28 days & $\begin{array}{l}\text { Cells were viable and grew actively on the scaffold as- } \\
\text { sisted by the perfusion culturing (dynamic condition). } \\
\text { Osteogenic development of hASCs was upregulated } \\
\text { by perfusion culturing }\end{array}$ & 51 \\
\hline Gao et al. & $\begin{array}{l}\text { Gelatin + sol-gel bioactive glass } \\
\left(70 \mathrm{SiO}_{2}-25 \mathrm{CaO}-5 \mathrm{P}_{2} \mathrm{O}_{5} \mathrm{~mol}-\%\right)\end{array}$ & $\begin{array}{l}\text { Cubic shaped scaffolds and a grid- } \\
\text { like microstructure }\end{array}$ & $\sim 30 \%$ & $\begin{array}{l}\text { Cell viability and } \\
\text { ALP activity }\end{array}$ & МС3Т3-Е1 & Up to 21 days & $\begin{array}{l}\text { Scaffolds supported cell proliferation, ALP activity, and } \\
\text { mineralization }\end{array}$ & 52 \\
\hline Richard et al. & $\begin{array}{c}\beta-T C P, \\
\beta-T M C P, \text { and BCMP }\end{array}$ & Inter-rod spacing of $\sim 460 \mu \mathrm{m}$ & $\begin{array}{l}\beta-\mathrm{TCP}=32 \% \\
\beta-\mathrm{TCMP}=45 \% \\
\mathrm{BCMP}=48 \%\end{array}$ & $\begin{array}{l}\text { MTT assay, } \\
\text { ALP, Osteocalcin, TGF- } \mathrm{\square} 1 \text {, and } \\
\text { Collagen }\end{array}$ & МСЗТ3-Е1 & 7,14 and 21 days & $\begin{array}{l}\text { No toxicity for this cell line. Calcium nodule formation } \\
\text { and bone markers activity suggested that the materi- } \\
\text { als would induce bone formation in vivo. }\end{array}$ & 53 \\
\hline Won et al. & $\begin{array}{l}\text { Fibronectin+ } \\
\text { glass }\left(85 \mathrm{SiO}_{2}-15 \text { nanobioactive }\right. \\
\qquad \mathrm{PCL}\end{array}$ & Bioactive nanocomposite scaffolds & $\begin{array}{l}\text { Pore size of } 0.5 \mathrm{~mm} \mathrm{x} \\
0.5 \mathrm{~mm}\end{array}$ & $\begin{array}{l}\text { Cell adhesion and } \\
\text { proliferation }\end{array}$ & rMSCs & 14 days & $\begin{array}{l}\text { Scaffolds significantly improved cells responses, in- } \\
\text { cluding initial anchorage and subsequent cell prolif- } \\
\text { eration }\end{array}$ & 54 \\
\hline Varanasi et al. & $\begin{array}{l}\text { PCL and PLA-hydroxapatite (70 } \\
\text { wt-\%) }\end{array}$ & 2D films and 3D porous sacffolds & $\sim 76 \%$ & MTT assay & МЗТЗ-Е1 & 7 days & $\begin{array}{l}\text { No deleterious influence of the polymer degradation } \\
\text { products on the cells and HA acted as a support for } \\
\text { osteoblast cytoskeletalal attachment, promoting their } \\
\text { proliferation }\end{array}$ & ${ }_{55}$ \\
\hline Andrade et al. & $\beta-T C P$ nd gelatin & $\begin{array}{l}\text { Flexible bioceramic scaffolds with } \\
\text { pore size of } \sim 200 \mu \mathrm{m}\end{array}$ & $45 \%$ & $\begin{array}{l}\text { Cell proliferation in static and dy- } \\
\text { namic conditions }\end{array}$ & МСЗТ3-Е1 & $\begin{array}{l}3,7,13 \text { and } 21 \\
\text { days }\end{array}$ & $\begin{array}{l}\text { Both culture systems fostered cell proliferation up to } \\
\text { day } 21 \text {, however, the dynamic methodology (oscilla- } \\
\text { tory flow wariation) achieved a higher cell proliferation }\end{array}$ & 56 \\
\hline $\begin{array}{l}\text { Martínez-Vázquez } \\
\text { et al. }\end{array}$ & Hydroxyapatite (HA) & $\begin{array}{l}\text { Prepared by drying at room tem- } \\
\text { perature or the freeze-drying } \\
\text { method }\end{array}$ & $71-77 \%$ & Cell Viability & МСЗТЗ & $1,3,7$, and 12 & $\begin{array}{l}\text { Freeze-dried scaffolds presented a significantly in- } \\
\text { crease in initial cell count and cell proliferation rate } \\
\text { when compared to the conventional evaporation } \\
\text { method }\end{array}$ & 57 \\
\hline Fiocco et al. & Silica-bonded calcite & $\begin{array}{l}\text { Two spacing between rods: } \\
\qquad \begin{array}{l}300 \mu \mathrm{m} \text { and } \\
350 \mu \mathrm{m}\end{array}\end{array}$ & $56 \%-64 \%$ & Cell adhesion and distribution & ST -2 cells & $1,3,7$ and 14 days & $\begin{array}{l}\text { Cells showed high metabolic activities and expressed } \\
\text { typical osteoplastic phenotype. Mineral deposit af- } \\
\text { ter cell cultivation was observed and all the scaffolds } \\
\text { stimulated cell adhesion and proliferation }\end{array}$ & 58 \\
\hline Stanciuc et al. & $\begin{array}{l}\text { Zirconia-toughened alumina } \\
\text { (ZTA) }\end{array}$ & $\begin{array}{l}\text { Robocasting of } 2 \mathrm{D} \text { pieces and } \\
3 \mathrm{D} \text {-ZTA scaffolds }\end{array}$ & $30-50 \%$ & $\begin{array}{l}\text { Cell viability, ALP activity, gene } \\
\text { expression and minera-lization }\end{array}$ & $\begin{array}{l}\text { human primary } \\
\text { osteo-blasts } \\
\text { (hob) }\end{array}$ & 10,20 and 30 days & $\begin{array}{l}\text { 2D-ZTA presented a higher ALP activity and an in- } \\
\text { creased hob cells proliferation than the DD-ZTA scaf- } \\
\text { foldds. RUNX2 was upregulated on all samples after } 10 \\
\text { days. }\end{array}$ & 59 \\
\hline Ben-Arfa et al. & $\begin{array}{l}\text { Sol-gel glass composition } \\
\left(64.4 \mathrm{SiO}_{-}-4.9 \mathrm{Na} \mathrm{Na}_{2}-21.53 \mathrm{C} \mathrm{CaO}\right. \\
\left.-3.09 \mathrm{P}_{2} \mathrm{O}_{5} \% \text { wt. }\right)\end{array}$ & $\begin{array}{l}\text { Different pore sizes }=300,400 \text { and } \\
500 \mathrm{am} \text {; with dimensions of } 3 \times 3 \\
\times 4 \mathrm{~m}\end{array}$ & $\sim 47 \%$ & $\begin{array}{l}\text { MTT assays according to ISO } \\
10993-5 \text { standard }\end{array}$ & $\begin{array}{l}\text { MG63 osteo- } \\
\text {-blasts }\end{array}$ & 7 days & $\begin{array}{l}\text { Within the pore size range tested, pore size did not ex- } \\
\text { ert any significant influence on cell viability, present- } \\
\text { ing no cytotoxicitity towards the osteoblasts }\end{array}$ & 60 \\
\hline
\end{tabular}

Table 1 - In vitro studies with robocast scaffolds from different materials. 


\begin{tabular}{|c|c|c|c|c|c|c|c|c|}
\hline Authors & Material Tested & Characteristics & Porosity & In Vivo Test & Animal Model & Time & Outcomes & Ref \\
\hline Liu et al. & Bioactive glass 13-93 & $\begin{array}{l}\text { Scaffolds BMP2 loaded and/or } \\
\text { pretreated in phosphate solution }\end{array}$ & $50 \%$ & Histomorpho-metric analysis & $\begin{array}{l}\text { Calvarial defects of } \varnothing 4.6 \mathrm{~mm} \\
\text { in rats }\end{array}$ & 6 weeks & $\begin{array}{l}\text { BMP-2 pre-conditioned scaffolds significantly enhanced } \\
\text { the capacity to support new bone formation }\end{array}$ & 59 \\
\hline Liu et al. & Bioactive glass 13-93 & $\begin{array}{l}6 \times 6 \times 6 \mathrm{~mm} \text { scaffolds, pore width } \\
\text { of } 300 \mu \mathrm{m}\end{array}$ & $47 \%$ & $\begin{array}{l}\text { Mechanical properties during in } \\
\text { vitro and in vivo tests }\end{array}$ & Subcutaneous model in rats & $\begin{array}{l}\text { Up to } 12 \\
\text { weeks }\end{array}$ & $\begin{array}{l}\text { In vivo reduction in mechanical properties was greater than } \\
\text { in vitro due to greater glass dissolution and faster conversion } \\
\text { of the glass into HCA }\end{array}$ & 30 \\
\hline Deliormanli et al. & Bioactive glass 13-93B & $\begin{array}{l}\text { Scaffolds with different pore sizes } \\
\quad=300,600 \text { and } 900 \mu \mathrm{m}\end{array}$ & $45-60 \%$ & $\begin{array}{l}\text { Histological exploring } \\
\text { tissue growth and blood vessel } \\
\text { infiltration }\end{array}$ & Subcutaneous model in rats & 4 weeks & $\begin{array}{l}\text { All scaffolds were infiltrated with fibrous tissue and blood } \\
\text { vessels. No difference was found in the formation of the fi- } \\
\text { brous tissue for the different pore sizes. }\end{array}$ & 60 \\
\hline Rahaman et al. & Bioactive glass 13-93 & $\begin{array}{l}\text { Scaffolds with or without BMP2 } \\
\text { and pretreatment in phosphate } \\
\text { solution }\end{array}$ & $50 \%$ & $\begin{array}{l}\text { Histological, histomorpho-metric } \\
\text { analysis and SEM }\end{array}$ & $\begin{array}{l}\text { Calvarial defects of } \varnothing 4.6 \\
\mathrm{~mm} \text { in rats }\end{array}$ & $\begin{array}{l}6,12 \text { and } \\
24 \text { weeks }\end{array}$ & $\begin{array}{l}\text { Bone regeneration increased with implantation time, and } \\
\text { pretreating and BMP2 loading significantly enhanced the } \\
\text { bone formation rate (for all studied times). }\end{array}$ & 61 \\
\hline Lin et al. & Bioactive glass 13-93 & $\begin{array}{l}\text { Scaffolds with or without BMP2 } \\
\text { loading }\end{array}$ & $47 \%$ & $\begin{array}{l}\text { Histological, SEM, and Histomor- } \\
\text { pho-metric analysis }\end{array}$ & $\begin{array}{l}\text { Calvarial defects of } \varnothing 4.6 \\
\mathrm{~mm} \text { in rats }\end{array}$ & $\begin{array}{l}6,12 \text { and } \\
24 \text { weeks }\end{array}$ & $\begin{array}{l}\text { BMP2 scaffolds significantly enhanced bone regeneration } \\
\text { and their pores were almost completely infiltrated with la- } \\
\text { mellar bone within } 12 \text { weeks. BMP2 scaffolds also had a sig- } \\
\text { nificantly higher number of blood vessels at } 6 \text { and } 12 \text { weeks. }\end{array}$ & 62 \\
\hline Simon et al. & Hydroxyapatite (HA) & $\begin{array}{l}\text { Scaffolds with different rod sizes } \\
\text { and porosities (different mac- } \\
\text { ro-pores channels) }\end{array}$ & $\begin{array}{l}\text { Different pore } \\
\text { channels. From } 250 \\
\text { to } 750 \mathrm{~m}^{2}\end{array}$ & $\begin{array}{l}\text { Micro-CT scans, histological and } \\
\text { SEM analysis }\end{array}$ & $\begin{array}{l}\text { Calvarial defects of } \varnothing 11 \mathrm{~mm} \\
\text { in rabbits }\end{array}$ & $\begin{array}{l}8 \text { and } 16 \\
\text { weeks }\end{array}$ & $\begin{array}{l}\text { Bone ingrowth at } 8 \text { and } 16 \text { weeks were comparable for all } \\
\text { samples. Bone attached directly to HA rods indicating os- } \\
\text { teoconduction. }\end{array}$ & 61 \\
\hline Dellinger et al. & Hydroxyapatite (HA) & $\begin{array}{l}\text { Scaffolds with and without BMP- } \\
2 \text { loading }\end{array}$ & $\begin{array}{c}\text { Pores of } 100-700 \\
\mu \mathrm{m}\end{array}$ & Histological analysis & $\begin{array}{l}\text { Metacarpal and metatarsal } \\
\text { bones defects of } \varnothing 6 \mathrm{~mm} \\
\text { in goats }\end{array}$ & $\begin{array}{l}4 \text { and } 8 \\
\text { weeks }\end{array}$ & $\begin{array}{l}\text { BMP-2 loaded scaffolds presented a significantly greater } \\
\text { bone formation at both experimental times. The cells used the } \\
\text { scaffolds as a template since the lamellar bone was aligned } \\
\text { near the scaffolds' rod junctions. }\end{array}$ & 62 \\
\hline Luo et al & $\mathrm{Ca}_{7} \mathrm{Si}_{2} \mathrm{P}_{2} \mathrm{O}_{16}$ & $\begin{array}{l}\text { Hollow-struts-packed (HSP) } \\
\text { bioceramic scaffolds }\end{array}$ & Up to $85 \%$ & Micro-CT and histological analysis & $\begin{array}{l}\text { Critical femoral bone defects } \\
\text { of } \varnothing 8 \times 10 \mathrm{~mm} \text { in rabbits }\end{array}$ & $\begin{array}{l}4 \text { and } 8 \\
\text { weeks }\end{array}$ & $\begin{array}{l}\text { HSP scaffolds possessed a superior bone-forming ability } \\
\text { and micro-CT analysis showed that the new bone started } \\
\text { to grow in the macropores and also into the hollow channels } \\
\text { of the scaffolds. }\end{array}$ & 63 \\
\hline Lin et al. & $\begin{array}{l}\text { Collagen and hydro- } \\
\text { xyapatite (CHA) }\end{array}$ & $\begin{array}{l}\text { Biomimetic 3D scaffolds via a } \\
\text { low-temperature process } \\
3 \text { rod widths: } 300,600 \text { and } 900 \\
\text { 4m }\end{array}$ & $72-83 \%$ & micro-CT and histological analysis & $\begin{array}{l}\varnothing 5 \mathrm{~mm} \text { defects in the femur } \\
\text { (condyle) of rabbits }\end{array}$ & $\begin{array}{l}2,4,8 \text {, or } \\
12 \text { weeks }\end{array}$ & $\begin{array}{l}\text { CHA scaffolds facilitated new bone growth, as the bioma- } \\
\text { terial was resorbed or incorporated into the newly formed } \\
\text { bone. CHA promoted better defect repair compared to the } \\
\text { nonprinted CHA scaffolds. }\end{array}$ & 64 \\
\hline Shao et al. & $\begin{array}{l}\text { Magnesium-doped } \\
\text { Wollastonite/ } \\
\text { TCP }\end{array}$ & $\begin{array}{l}\text { CSi-Mg10 }(10 \text { mol\% of Mg in } \\
\text { CSi), } \\
\text { CSi-Mg10/TCP15 (15-wt\% TCP } \\
\text { content) and pure } \beta \text {-TCP. }\end{array}$ & $52-60 \%$ & $\begin{array}{l}\text { Micro-CT, histological and me- } \\
\text { chanical tests }\end{array}$ & $\begin{array}{l}\text { Calvarial defects of } \oslash 8 \mathrm{~mm} \\
\text { in rabbits }\end{array}$ & $\begin{array}{l}4,8 \text { and } 12 \\
\text { weeks }\end{array}$ & $\begin{array}{l}\text { CSi-Mg10/TCP15 scaffolds displayed higher osteogenic } \\
\text { capability when compared to CSi-Mg10 and -TCP affer } 8 \\
\text { weeks. After } 8 \text { and } 12, \text { CSi-Mg10//CP15 presented an in- } \\
\text { crease in their mechanical properties, possibly due to the } \\
\text { new bone tissue ingrowth into the scaffolds }\end{array}$ & 65 \\
\hline
\end{tabular}

Table 2 - In vivo studies with robocast scaffolds from different materials. 
Fully dense monolithic bioceramics

When developing dense bioceramics by robocasting several parameters should be examined in a sequential step process that should be used to plan new studies. Based on information regarding the materials and the processing parameters, it is possible to create a
development strategy. This is shown in Figure 3.

Figure 3 shows the level of complexity associated with the develop-

ment of new ceramic inks. It necessarily involves a technical study aimed

and morphology) on the ink. At the same time, it is crucial to understand he interaction of the ceramic material with the fluid selected for the ink mantacture, l.e., which additives can be used to achieve a stable and the printing strategy and for the robocasting processing parameters to The following

ections detail the relevant parameters to guide future at understanding the effects of solid fractions (particle quantities, sizes,

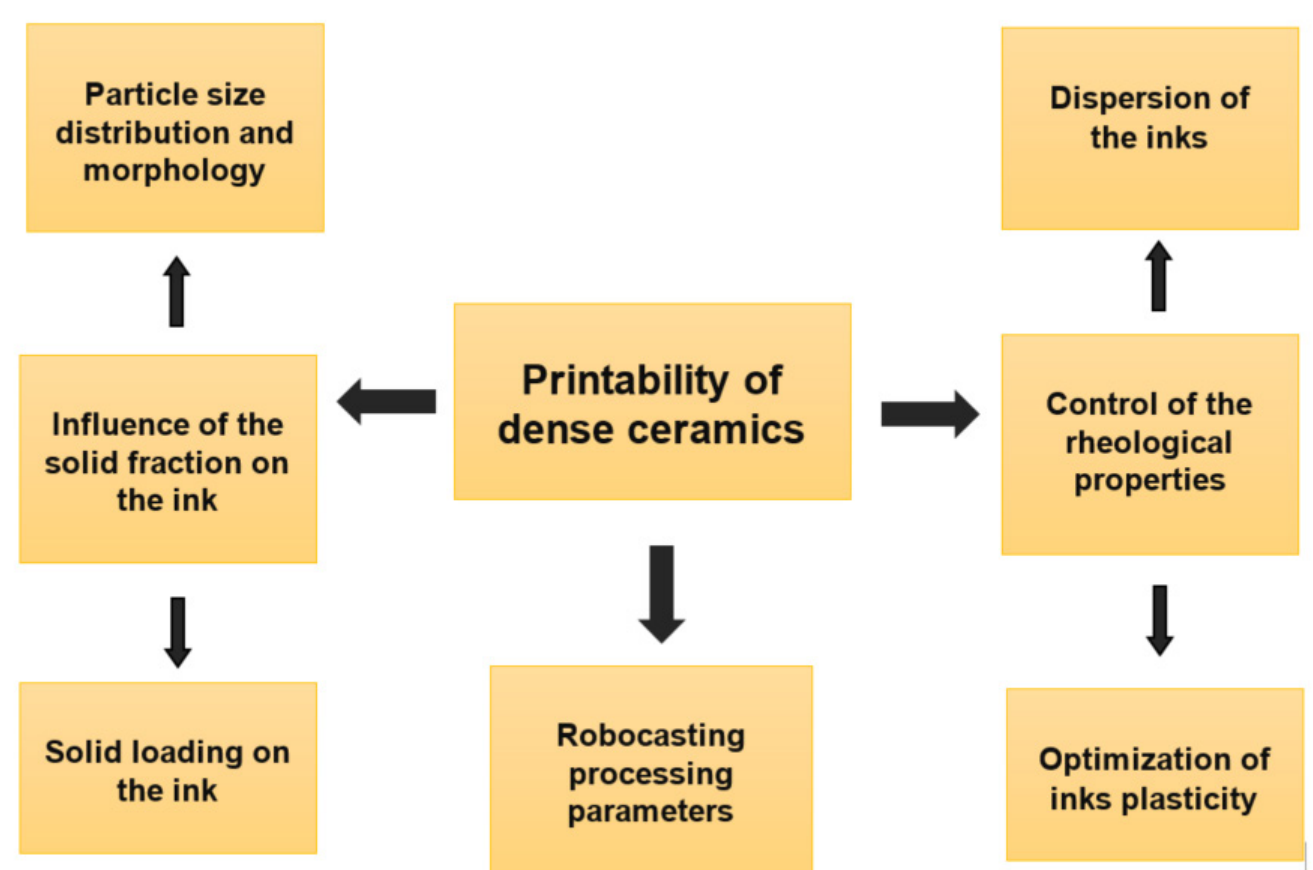

Figure 3 - Robocasting suspension development strategy.

\section{Morphology and Particle size distribution}

There is a consensus in the literature on the need for highly refined starting powders with broad particle size distribution to maximize green body compactability and sinterability. $.0,0,0,00$ in parallel, some authors state that solid loads with bimodal distributions induce a reduction of the ink's viscosity when compared to suspensions manufactured with monomoda Ohero and Ferreira fabricated the stater pouder sy The authors found that the viscosity of the suspensions increased as the percentage of fine powders increased and, contrary to common sense, the powders with a high concentration of coarse solids showed a decrease in viscosity. This fact is due to the rheological behavior of the powders against the shear stress.

Particle morphology, on the other hand, affects the rheology of suspensions secondarily, due to the dispersed solids content and particle size distribution, being much more impactful in colloidal suspensions. geneous morphologies, are more susceptible to shear flow than those

heology of two groups of graphite particles hat suspensions made with spherical particles had a significantly lower viscosity than those made with particles of anisotropic morphology. Regarding the shear flow mechanism, this phenomenon is explained by the resistance promoted by the viscous suspension to the rotation of the
elongated particles against the ease of spherical particles, which offer

Figure 4 - Cross section of dried platelet paste, with the location of several bubbles marked. Reproduced with permission. ${ }^{76}$
Mass solids content

possible, the ideal solids $c 00$ and never below $30 \%(\mathrm{~V} / \mathrm{N})$, this would grant a dimensional and geometric predictability after sintering. $77,78 \mathrm{Table} 3$ presents some shrinkage results for different materials and additives as a function of the volume of sus-
pended solids.

\begin{tabular}{|c|c|c|c|c|}
\hline Materials & Additives used & $\begin{array}{c}\text { Solid loading } \\
(v / v)\end{array}$ & Linear shrinkage & Ref. \\
\hline 3Y-TZP & $\begin{array}{l}\text { PEG-DA, DEG and DiphenyI } \\
\text { (2,4,6-trimethylyenzayy) } \\
\text { phosphine oxide }\end{array}$ & $37,5 \%$ & $228 \%$ & \\
\hline 3Y-TZP & $\begin{array}{l}\text { PVA }(M W \text { 31000), PEG (MW } \\
400), C_{6} H_{8} O_{6} \text { and } \mathrm{C}_{6} H_{8} \mathrm{O} 7\end{array}$ & $38 \%$ & $33 \%$ & 8 \\
\hline $\mathrm{Si}_{3} \mathrm{~N}_{4}$ & H-PEl, L-PEI and HPMC & 35\% & 28\% & 7 \\
\hline $\mathrm{Si}_{3} \mathrm{~N}_{4}$ & $\begin{array}{l}\text { Darvan 821A, itrici acid and } \\
\text { ammonium hydroxide }\end{array}$ & $52 \%$ & $16 \%$ & \\
\hline $\mathrm{Al}_{2} \mathrm{O}_{3}$ & $\begin{array}{l}\text { Dolapix CA, magnesium } \\
\text { chloride and Alginic acid }\end{array}$ & $45 \%$ & 26\% & \\
\hline $\mathrm{Al}_{2} \mathrm{O}_{3}$ & $\begin{array}{l}\text { Darvan C-N, Bermocoll E } \\
\text { and a polyethlyene-imine } \\
\text { solution }\end{array}$ & $56 \%$ & $\sim 17 \%$ & \\
\hline $\mathrm{Al}_{2} \mathrm{O}_{3}$ & $\begin{array}{l}\text { Dolapix CE } 64 \text {, PEG } 400 \text { and } \\
\text { methocelllulose }\end{array}$ & $55 \%$ & $15-19 \%$ & \\
\hline
\end{tabular}

Table 3 - Linear shrinkage as a function of solid loading for some bioceramic inks.

Moreover, the literature reiterates that suspensions with high saturation, greater than $50 \%$ (v/v) produce parts with high densification sutes and low shinkage and warp. Neverheless, hhe stabilzation of analysis, mainly due to the need of controlling the shear stresses during the extrusion process. $79,80,81$ In general, the increase in mass viscosity with increasing volume of suspended solids can be directly attributed to the fact that a higher volumetric fraction of suspended ceramic particles further restricts the media flow. ${ }^{82}$

\section{Rheological stabilization of suspensions}

Controlling the rheological properties of the filament is essential to prevent sag and part deformation after filamentextusion, especially when geometry includes complex shapes and bridged structures such as in scaffolds. An adequate behavior can be achieved in some ways, such as by controlled flocculation of the ceranic suspension to form a gel (e.g., change in $\mathrm{pH}$, solvent ionic strength, the addition of polye

The litertu adighights three mechanism of solids

Thension: electrostatic stabilization, arising fom the pre encesence of the attraction promoted by the van der Waals forces: steric stabilization where the adsorption of polymers on the surface of the suspended materia promotes the mechanical immobilization of the particles; and electrosteric stabilization, a combination of electrostatic and steric stabilization, where polyelectrolytes are adsorbed on the surface of the particles and ions from the dissociation of the polyelectrolytes promote an adjacent electrostatic barrier. $80,8,8,50$ The mechanisms are demonstrated in Figure 5 .

For the study of the stability of suspensions, a handy tool is the Zeta potential measurement, as it describes the potential difference between the dispersion medium and the stationary layer of boundary fluid at the surface of the dispersed particles. In other words, the technique makes it possible to assess the variation of a repulsive or atractive tendency among be used to predict and control suspension stability. From this knouledge, he interaction forces can be adjusted accordingly, from a highly dispersed state in which repulsion forces dominate to a weakly flocculated or even strongly aggregated state by which attractive forces are predominant. In the case of aqueous suspensions with high solids concentration, it is common to use polyelectrolytes containing ionizable functional groups, such as amine $\left(-\mathrm{NH}_{2}\right)$ or carboxylic $(-\mathrm{COOH})$, for electrostatic stabilization, in addition to $\mathrm{pH}$ control.8990,9,9 pritability, such as viscosity between 10 and $100 \mathrm{~Pa}$.S, elastic modulus to possess ming, concentrated ceramic suspension for robocasting has

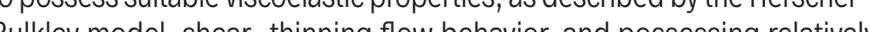
high modulus (G) with $t>200$ Pa to allow structural self-s party abrication of high aspect ratio structures (Figure 6). 6 .

For this optimization, appropriate rheological modifiers, such as flocculating/binder agents, should be added to the already stabilized, i.e. deflocculated, suspensions 18,79,86 In the usual approach to obtain the deal parameters, reported in the literature, it is proposed the use of a deflocculating agentcharge binder, as opposed to the one used for the dispersion of the particles. $.8,8,788$ This addition intends to control flocculation by promoting a reduction of the adsorbed layer. This procedure improves

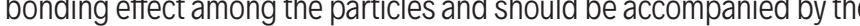
aldion of a rheological modifier, usually a long-chain polymer, aimed a parameters. 列

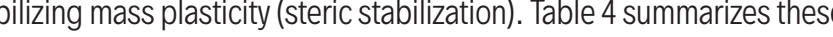




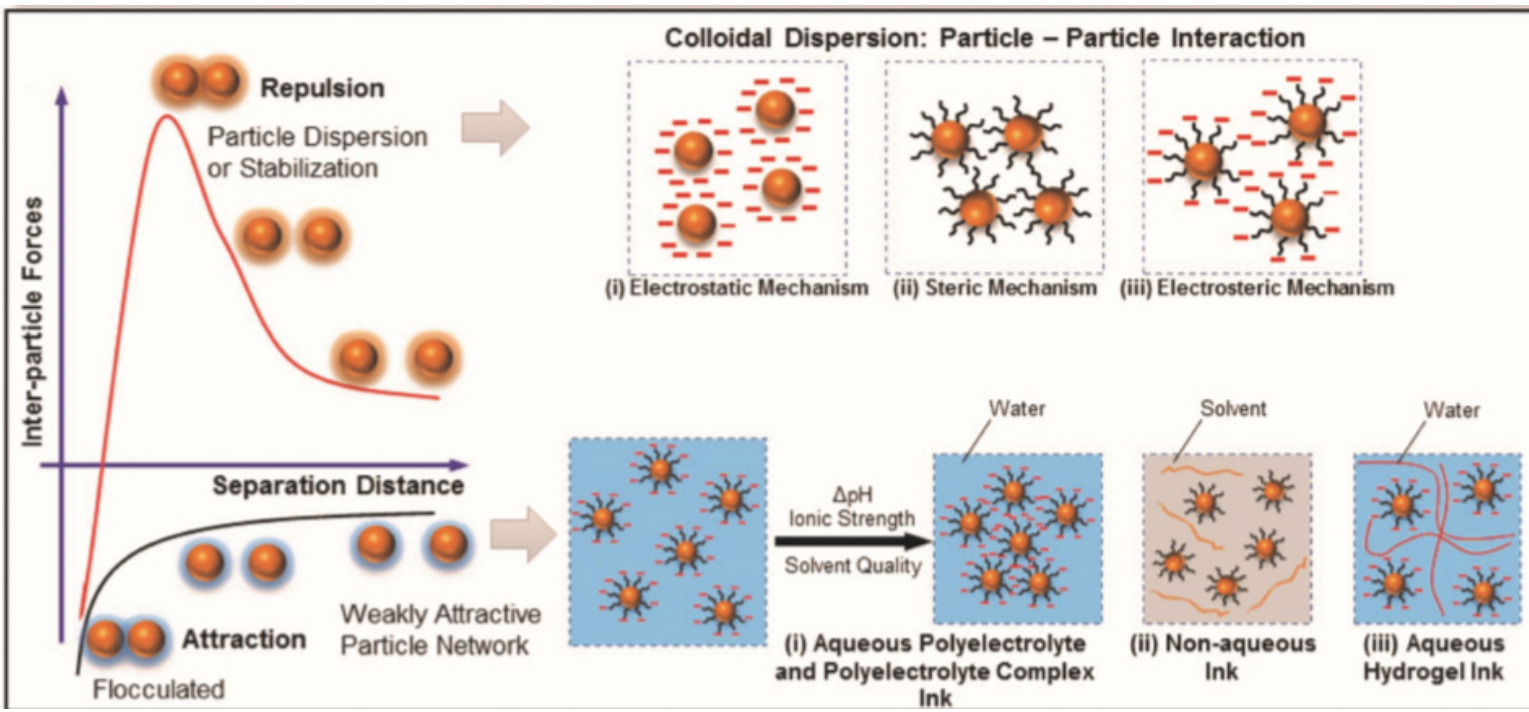

Figure 5 - Representation of mechanisms to improve the particle dispersion. Reproduced with permission. 6 Copyright 2018, John Wiley and Sons.
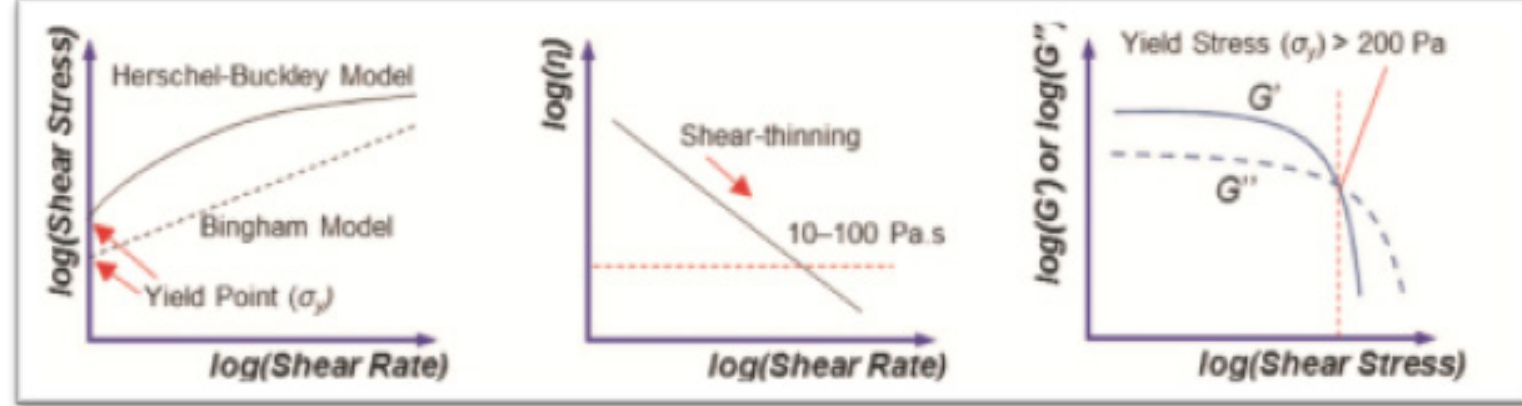

Figure 6 - Rheological behaviors required for ceramic robocasting. Reproduced with permission. ${ }^{6}$ Copyright 2018, John Wiley and Sons.

\begin{tabular}{|c|c|c|c|c|c|c|c|}
\hline \multirow{2}{*}{ Materials } & \multicolumn{3}{|c|}{ Additives used } & \multirow{2}{*}{$\begin{array}{l}\text { Solid } \\
\text { loading } \\
\text { (v/v) }\end{array}$} & \multirow{2}{*}{$\begin{array}{c}\text { Average } \\
\text { grain size } \\
\left(d_{50}\right)\end{array}$} & \multirow{2}{*}{$\begin{array}{l}\text { Relative } \\
\text { density }\end{array}$} & \multirow{2}{*}{ Ref } \\
\hline & Dispersants & $\begin{array}{l}\text { Flocculant / } \\
\text { binder }\end{array}$ & $\begin{array}{l}\text { Rheological } \\
\text { modifier }\end{array}$ & & & & \\
\hline $\mathrm{SiC}$ & \multicolumn{3}{|c|}{ Darvan 670, PEG 10.000 and $\mathrm{NH}_{4} \mathrm{AC}$} & $44 \%$ & $0.7 \mathrm{am}$ & $\sim 95 \%$ & 89 \\
\hline $\mathrm{Al}_{2} \mathrm{O}_{3}$ & \multicolumn{3}{|c|}{ Pluronic F-127 } & $39 \%$ & $0.3 \mathrm{am}$ & $\sim 97 \%$ & 17 \\
\hline $\mathrm{Al}_{2} \mathrm{O}_{3}$ & \multicolumn{3}{|c|}{ Darvan C, psyllium and Glycerol } & $49 \%$ & $0.4 \mathrm{\square m}$ & $\sim 98 \%$ & 85 \\
\hline $\mathrm{Al}_{2} \mathrm{O}_{3}$ & Darvan 821A & & & $55 \%$ & $0.6 \mathrm{am}$ & $92 \%$ & 86 \\
\hline 3Y-TZP & \multicolumn{3}{|c|}{ Dolapix CE $64 / \mathrm{NH}_{4} \mathrm{OH}$} & $50 \%$ & $0.04 \mathrm{gm}$ & $\sim 99 \%$ & 87 \\
\hline 3Y-TZP & $\mathrm{C}_{6} \mathrm{H}_{8} \mathrm{O}_{6} / \mathrm{C}_{6} \mathrm{H}_{8} \mathrm{O}_{7}$ & $\begin{array}{l}\text { PVA (MW } \\
31000)\end{array}$ & PEG (MW 400) & $38 \%$ & $\sim 0.4 \mathrm{am}$ & $94 \%$ & 8 \\
\hline $\mathrm{Si}_{3} \mathrm{~N}_{4}$ & \multicolumn{2}{|c|}{ H-PEI/L-PEI } & HPMC & $52 \%$ & $0.77 \mathrm{am}$ & $\sim 99 \%$ & 7 \\
\hline $\mathrm{Si}_{3} \mathrm{~N}_{4}$ & H-PEI/L-PEI & Darvan-821 & HPMC & $44 \%$ & $0.5 \mathrm{am}$ & $97 \%$ & 27 \\
\hline
\end{tabular}

Table 4 - Relationship between additives used, suspended solids loading, average particle size, and relative density of the final part.

Finally, some equations are presented as support for the controlling of printable height $\left(\mathrm{h}_{\mathrm{m} \text {, }}\right.$ of a free wall, without the risk that it will of collapse parameters and print design. The ideal volumetric flow rate (Q) to fill the due to gravitational action, Equation (4).

path taken by the print nozzle, ensuring the maintenance of the predicted

specimenthis

Severa authors suggest Equation (1) to specify this parameter. 16,17.55,86

$$
h_{\max }=\frac{\sigma_{y}^{D_{y n}}}{\rho g}
$$

$$
Q=\left(\pi r^{3} / 4\right) \cdot \dot{r}
$$

- where: $\mathrm{Q}=$ ideal volumetric flow rate $\left(\mu \mathrm{m}^{3} \mathrm{~s}\right) \mathrm{r}=$ radius of extrusion nozzle $(\mu \mathrm{m})$ and $(\dot{\gamma})=$ shear rate $\left(\mathrm{s}^{-1}\right)$.

Since suspensions used in robocasting must have a dispersed solids fraction higher than $30 \%(\mathrm{~V} / \mathrm{N})$, they eventually exhibit shear-thinning flow behavior. Thus, several authors claim that the Herschel-Bulkley model, Equation (2), satisfactorily describes the degree in which the ink presents a shear-thinning or shear-thickening behavior.,3,5,

$$
\sigma=\sigma_{y}^{D_{y, m}}+K \gamma^{n}
$$

where: $\sigma^{D_{y n}}$ is the dynamics vield stress $(\mathrm{Pa}), \rho$ is the specific weight whe ink and $\mathrm{g}$ is the gravitational contribuition $\left(9.81 \mathrm{~m} / \mathrm{s}^{2}\right)$

A Cime can be incorporated into the conventional concept of sD printing

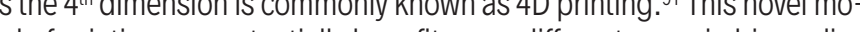
application can potentally benefit many aiferent areas in biomedica applications, such as tissue regeneration, medical device fabrication, and drug delivery. ${ }^{92}$

where: $\sigma=$ shear stress $(\mathrm{Pa}), \sigma \_\mathrm{y}^{\wedge}\left(\mathrm{D} \_\mathrm{yn}\right)=$ dynamic yield stress $(\mathrm{Pa}), \mathrm{K}=$ viscosity parameter $\left(\mathrm{Pa} \cdot \mathrm{s}^{\mathrm{n}}\right), \gamma=$ shear rate $\left(\mathrm{s}^{-1}\right)$ and $\mathrm{n}$ shear exponent, for $n<1$ the fluid is shear-thinning, whereas for $n>1$
the fluid is shear-thickening. Smavetal. proposed another

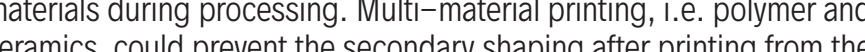
polymeric materials. ${ }^{93} \mathrm{In}$ most of the reported AM techniques, the form of the as-printed green body usually dictates the final shape of the sintered structure, while post-printing secondary shaping of the green body obtained from the AM process is minimal. However, a deep understanding on how external stimuli such as temperature, moisture, light, magnetic field, electric field, pH, ionic concentration or chemical compounds can affect the characteristics of the printed materials is yet to be established. Another possibility in the AM field is the obtention of smart materials. strategy and extrusion parameters. ${ }^{93}$ The authors described an $p$ to predict the maximum span by which a structure can be constructed in green without experiencing deformation, as depicted in Equation (3). .9. $^{9}$

(3) such as controlled swelling, predicted shape alterations, functionalities $G^{\prime} \geq 1.4 \cdot \rho \cdot S^{4} D$ such as controlled swelling, predicted shape alterations, functionalities twisting or combinations of these two basic movements, can be implemented by programming the material's microstructure to undergo loca anisotropic shrinkage during heat treatment, as presented in Figure 8 . This functional design may be achieved by magnetically aligning functionalized ceramic platelets in a liquid ceramic suspension, subsequently consolidated through an established enzyme-catalysed reaction, and finally Regarding the robocasting process, geopolymeric slurries could be of the ink. 7 iguremplifies a case in which the poor stab ink leads to a completely collapse of the structure.
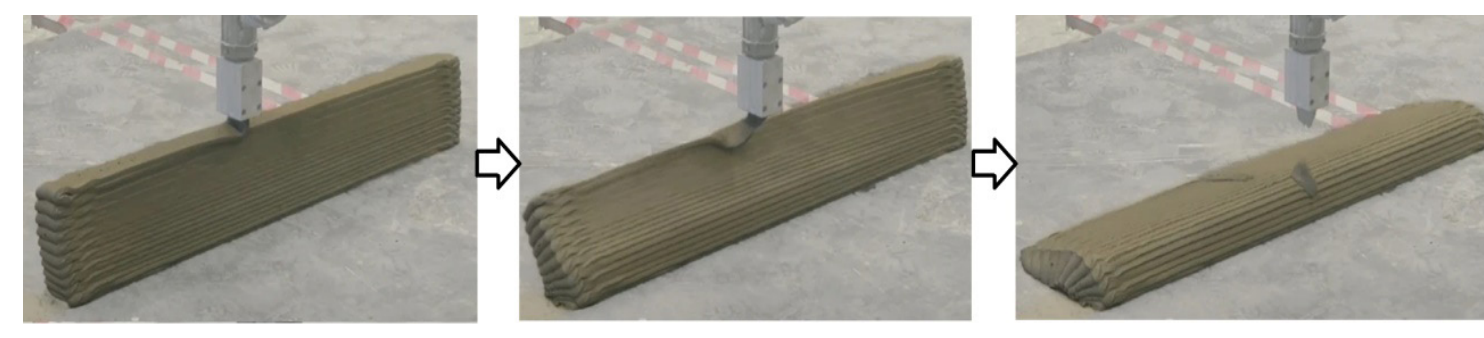

erimental buckling response of the free wall, the three stages of failure: buckling initiation, buckling development and full collapse. Reproduced with permission. 96

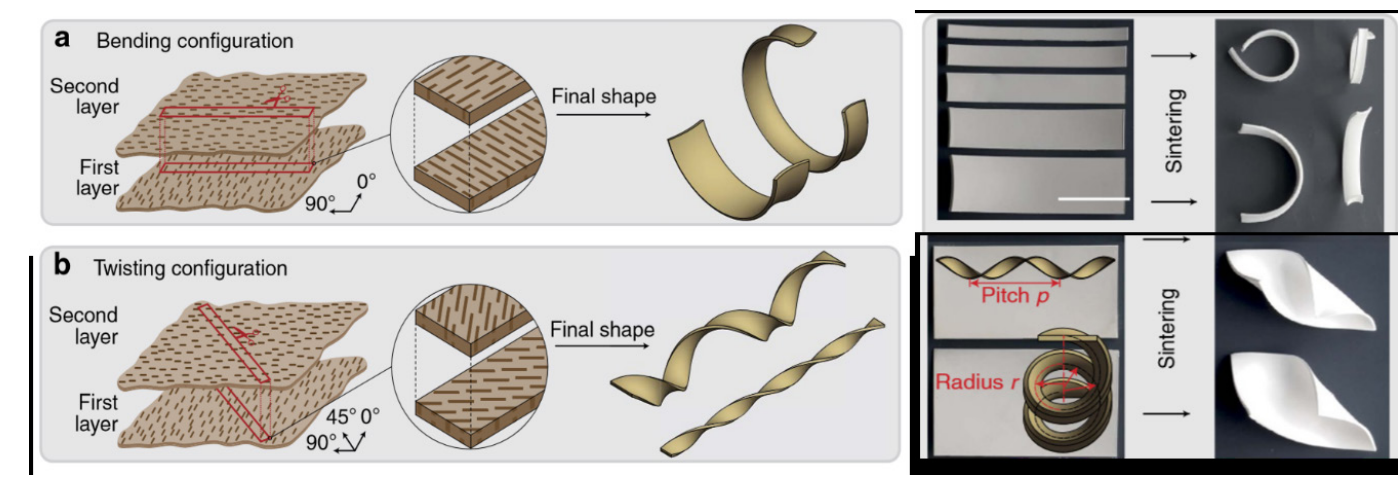

Figure 8 - Illustration of the proposed self-shaping mechanism: (a) bending and (b) twisting configuration, based on bottom-up shaping method of ceramic suspensions. Reproduced with permission: 102 
good candidates as smart materials for $4 \mathrm{D}$ printing provided their reaction over time could be effectively controlled. ${ }^{96}$ However, within bioceramic content, the evidence on works reported in 4D systems does not show specific cases that support these advances.

In the last decades, a discussion on how to relate AM and TE brought up another printing concept, a new bottom-up printing system. This emerging technology, also called bioprinting, relies on the possibility of into larger tissue constructs. Bottom-up TE means to pattern the individual components of one tissue according to a predefined organization vidual components of one tissue according to a predefined organization
that guides the maturation of the construct towards a functional histoarchitecture, owing in part to the promotion of cellular self-sorting and self-assembly capabilities and morphogenetic mechanisms. ${ }^{97}$ However, for this process cells are a mandatory component of a bioink. So, obtaining a formulation that includes biologically active elements or molecules and also the biomaterials is a challenge that is still to be faced. To the best of our knowledge, up to this date, no study has been dedicated to the development of a functional bioink to be processed by robocasting. Up
to now, robocasting technology has been mostly employed in the fabrito now, robocasting technology has been mostly employed in the fabrication of a wide range of technical and functional scaffolds with complex morphologies. In order to push the progress of this processing method allow the fabrication of unique and exciting architectures beyond simple robocasting technique.

As presented in this review, the key factor towards multi-material printing and other AM future technologies relies on multidisciplinary researc to face all the imposed challenges. Developing new ink formulations for robocasting bioprinting as well as designing smart materials will certain trate the potential of AM in the biomedical field.

\section{Acknowledgement}

ould like to thank the São Paulo Research Foundation - FAPESP, grant number 2019/11950-6. C Santos would like to thank the FAPERJ (E-26-201.476/2014) and CNPq (308684/2013-3 and $3311119 / 2017-4$ ) for financial support. M Souza is grateful to $3-6$. São Paulo Research Foundation - Fapesp, grant number 2013/00793-6. Also, J. Daguano is grateful to 0 Amorim for providing graphical art help MHV Fernandes acknowledges the project CICECO-Aveiro Institut of funds through the Portuguese Foundation for Science and Technology/
MCTES

\section{References}

1. Salerno A, Netti PA, Introduction to biomedical foams, in Biomedical Foams for Tissue Engineering Applications, ed by Netti PA. Woodhead Publishing, pp 3-39 (2014)

2. Cesarano J, Calvert PD, and Inventor: Sandia Corporation, Assignee, Freeforming Objects with Low-Binder Slurry. US Patent

3. Lewis JA, Smay JE, Stuecker J, Cesarano J, Direct ink writing of threedimensional ceramic structures. J Am Ceram Soc 89 : 3599(2006).

4. Johansson $E$, Lidström $\mathrm{O}$, Johansson J, Lyckfeldt $\mathrm{O}$, Adolfsson $\mathrm{E}$, manufactured by stereolithography. Mater 10:138 (2017).

5. Peng E, Zhang D, Ding J, Ceramic Robocasting: Recent Achieve-
ments, Potential, and Future Developments. Adv Mater 30 (47) 1802404(1-14) (2018)

6. Stuecker JN, Cesarano J, Hirschfeld DA, Control of the Viscous Be- havior of Highly Concentrated Mullite Suspensions for Robocasting. J Mater Process Technol 142 [2] 318-25 (2003).

Zhao S, Xiao W, Rahaman MN, O'Brien D, Seitz-Sampson JW, Sonny Bal B, Robocasting of silicon nitride with controllable shape

Barry III AR, Shepherd RF, Hanson JN, Nuzzo RG, Wiltzius P, Lewis JA, DirectaWrite Assembly of $3 \mathrm{D}$ Hydrogel Scaffolds for Guided Cel Growth. Adv Mater 21: 2407-2410 (2009).

9. Casas-Luna M, Tan H, Tkachenko S, Salamon D, Montufar EB, Enhancement of mechanical properties of 3D-plotted tricalci4366-4374 (2019).

0. Bose S, Ke D, Sahasrabudhe H, Bandyopadhyay A, Additive manufacturing of biomaterials. Prog Mater Sci 93: 45-111 (2018).

11. Leong KF, Cheah CM, Chua CK. Solid freeform fabrication of three-dimensional scaffolds for engineering replacement tissues and organs. Biomater 24:2363-78 (2003).

12. Murphy SV, Atala A. 3D bioprinting of tissues and organs. Nat Biotechnol 32:773-85 (2014).

13. Fielding G, Bose S. $\mathrm{SiO}_{2}$ and $\mathrm{ZnO}$ dopants in three-dimensionalIy printed tricalcium phosphate bone tissue engineering scaffolds enhance osteogenesis and angiogenesis in vivo. Acta Biomater 9:9137-48 (2013)

14. Woodfield TBF, Malda J, de Wijn J, Péters F, Riesle J, van Blitterswijk CA. Design of porous scaffolds for cartilage tissue engineering using a threedimensional fiber-deposition technique. Biomater 25:4149-61 (2004).

15. Eqtesadi S, Motealleh A, Perera FH, Miranda P, Pajares A, Wendelbo R, Guiberteau F, Ortiz AL, Fabricating geometrically-complex $\mathrm{B}_{4} C$ ceramic components by robocasting and pressureless spark plasma sintering. Scr Mater 145: 14-18 (2018)

16. Feilden E, Blanca EGT, Giuliani F, Saiz E, Vandeperre L, Robocasting of structural ceramic parts with hydrogel inks. J Eur Ceram Soc

17. Quackenbush CL, French K, Neil JT, Fabrication of sinterable silicon intride by injection molding. Ceram Eng Sci Proc 3:(1-2) Chapter 3 (1982)

18. Millan AJ, Nieto MI, Moreno R, Aqueous injection moulding of silicon nitride. J Eur Ceram Soc 20:2661-2666 (2000).

19. Albano MP, Garrido LB, Processing of concentrated aqueous slicon nitride slips by slip casting. J Am Ceram Soc 81:837-844 (1998).

20. Wan T, Yao T, Hu H, Xia Y, Zuo K, Zheng Y, Fabrication of porous $\mathrm{i}_{3} \mathrm{~N}_{4}$ ceramics through a novel gelcasting method. Mater Let

21. Griffith ML, Halloran JW, Freeform Fabrication of Ceramics via Stereolithography. J Am Ceram Soc 79(10): 2601-8 (1996).

22. Homa J, Schwentenwein M, A Novel Additive Manufacturing Technology for High-Performance Ceramics, in Advanced Processing
and Manufacturing Technologies for Nanostructured and Multi- functional Materials. Ceramic Engineering and Science Proceedings, ed by Ohil T, Singh M, Mathur S. John Wiley \& Sons, Inc. Hoboken, NJ, pp. 33-40 (2014)

23. Cesarano $\mathrm{JIII}$, Segalman R, Calvert P, Robocasting provides moldless fabrication from slurry deposition. Ceram Ind 148:94-102

24. Lewis JA, Smay JE, Stuecker J, Cesarano J III, Direct ink writing of threedimension
3609 (2006)

25. Cai K, Román-Manso B, Smay JE, et al, Geometrically complex silicon carbide structures fabricated by robocasting. I Am Ceram Soc 95:2660-2666 (2012)

26. He GP, Hirschfeld DA, Cesarano IIII, Stuecker JN, Robocasting and Recort, Sandia National Laboratory, SAND2000-1493C (2000).

27. Fu Q, Saiz E, Tomsia AP, Direct ink writing of highly porous and strong glass scaffolds for load-bearing bone defects repair and regeneration. Acta Biomater 7:3547-3554 (2011).

28. Liu X, Rahaman MN, Hilmas GE, Bal BS, Mechanical properties of bioactive glass (13-93) scaffolds fabricated by robotic deposition

29. Xiao W, Zaeem MA, Bal BS, Rahaman MN, Creation of bioactive glass (13-93) scaffolds for structural bone repair using a combined finite element modeling and rapid prototyping approach Mater Sci Eng C 68:651-662 (2016).

30. Paredes C, Martínez-Vázquez FJ, Pajares A, Miranda P, Novel strategy for toughening robocast bioceramic scaffolds using polymeric cores. Ceram Int 45:19572-19576 (2019).

31. Gu GX, Libonati F, Wettermark SD, Buehler MJ, Printing nature: Unraveling the role of nacre's mineral bridges. J Mech Behav Biomed Mater 76: 135-144 (2017).

32. Soon G, Pingguan-Murphy B, Lai KW, Akbar SA, Review of Zirconia-based bioceramic: Surface modification and cellular response. Ceram Int 42(11): 12543-12555 (2016).

33. Baino F, Novajra G, Vitale-Brovarone C. Bioceramics and Scaffolds: A Winning Combination for Tissue Engineering. Front Bioeng Biotechnol 3.202 (2015)

34. Hongshi Ma, Chun Feng, Jiang Chang, Chengtie Wu, 3D-printed bioceramic scaffolds: From bone tissue engineering to tumor therapy. Acta Biomater 79: 37-59 (2018).

35. Mordor Intelligence, Bioceramics Market - Growth, Trends, And Forecast (2019 - 2024). https://www.mordorintelligence.com/ industry-reports/bioceramics-market [accessed 9 September 2019].

36. Cengiz IF, Pitikakis M, Cesario L, Parascandolo P, Vosilla L, Viano $G$, et al., Building the basis for patient-specific meniscal scaffolds: from human knee MRI to fabrication of 3D printed scaffolds. Bio-

37. Do AV, Khorsand B, Geary SM, Salem AK, 3D printing of scaffolds for tissue regeneration applications. Adv Healthc Mat 4: 1742 1762. (2015). doi: $10.1002 / \mathrm{adhm} .201500168$
38. Duarte Campos DF, Blaeser A, Buellesbach K, Sen KS, Xun W, Tillmann W, et al., Bioprinting organotypic hydrogels with improved mesenchymal stem cell remodeling and mineralization properties
for bone tissue engineering. Adv Healthc Mater 5: 1336-1345 for bone tissue engineering. Adv Healh
(2016). doi: 10.1002/adhm.201501033

39. Jang J, Park HJ, Kim SW, Kim H, Park JY, Na SJ, et al., 3D printed (a) (2017). doi:10.1016/J.BIOMATERIALS.2016.10.026

40. Hwa LC, Rajoo S, Noor AM, Ahmad N, Uday MB, Recent advances in $3 D$ printing of porous ceramics: A review. Curr Opinion Sol State Mater Sci 21: 323-347 (2017).

41. Nommeots-Nomm A, Lee PD, Jones JR. Direct ink writing of highly bioactive glasses. J Eur Ceram Soc 38: 837-844 (2018).

42. Eqtesadi S, Motealleh A, Miranda P, Lemos A, Rebelo A, Ferreira JMF. A simple recipe for direct writing com
scaffolds. Mater Letters 93: 68-71 (2013).

43. Koski C, Onuike B, Bandyopadhyay A, Bose S. Starch-hydroxyapatite composite bone scaffold fabrication utilizing a slurry exdit Manuf 24: 47-59

44. Miranda P, Pajares A, Saiz E, Tomsia AP, Guiberteau F, Fracture Modes Under Uniaxial Compression in Hydroxyapatite Scaffolds (2007)

45. Dellinger JG, Cesarano J, Jamison RD, Robotic Deposition of Model Hydroxyapatite Scaffolds with Multiple Architectures and Multiscale Porosity for Bone Tissue Engineering. I Biomed Mater Res A 82A(2): 383-94 (2007).

46. Marques CF, Perera FH, Marote A, Ferreira S, Vieira SI, Olhero S, Miranda P, Ferreira JMF, Biphasic calcium phosphate scaffolds al and osteoblastic properties. J Eur Ceram Soc 37(1):359-368 (2017).

47. Chung-Hun OH, Seok-Jung Hong, IJ, Hye-Sun Y, Seung-Hwan J, Hae-Won K, Development of Robotic Dispensed Bioactive Scaffolds and Human Aalpose-Derived Stem Cell Culturing for Bone Tissue Engineering. Tissue Eng Part C 16(4): 561-71 (2010). do

48. Gao C, Rahaman MN, Gao Q, Teramoto A, Abe K, Robotic deposition and in vitro characterization of $3 \mathrm{D}$ gelatin-bioactive glass A 101(7): 2027-37 (2013). doi: 10.1002/jbm.a.34496.

49. Richard RC, Sader MS, Dai J, Thir RMSM, Soares GDA, Beta-type calcium phosphates with and without magnesium: From hydrolysis of brushite powder to robocasting of periodic scaffiolds. J Biomed

50. Won JE, Mateos-Timoneda MA, Castano O, Planell JA, Seo SJ, Lee EJ, Han CM, Kim HW, Fibronectin immobilization on to robotic-dispensed nanobioactive glass/polycaprolactone scaffolds for bone tissue engineering. Biotechnol Lett 37(4): 935-42 (2015). doi: 10.1007/s10529-014-1745-5.

51. Varanasi VG, Russias J, E, Loomer PM, Tomsia AP. Novel PLA- 
and PCL-HA Porous 3D Scaffolds Prepared by Robocasting Facilitate MC3T3-ET Subclone 4 Cellular Attachment and Growth. In: Biomaterials Science: Processing, Properties, and Applications V: Ceramic Transactions, Volume 254. (2015). https://doi. org/10.1002/9781119190134.ch16

52. Andrade S, Abdalla A, Montufar E, Corté L, Vanegas P. Fabrication of $3 D$ Bioactive Ceramic Scaffolds by Robocasting. In: Braidot A
Hadad A (eds) VI Latin American Congress on Biomedical Engineering CLAIB 2014, Paraná, Argentina 29, 30 \& 31 October 2014. IFMBE Proceedings, vol 49. Springer, Cham, (2015).

53. MartínezzVázquez F, Pajares A, Miranda P, Effect of the drying process on the compressive strength and cell proliferation of hydroxyapatitenderived scaffolds. Int J Appl Ceram Tec (2017). https://doi.org/10.1111/ijac.12755.

54. Fiocco L, Elsayed H, Badocco D, Pastore P, Bellucci D, Cannillo $\checkmark$, Detsch R, Boccaccini AR, Bernardo E, Direct ink writing of silica-bonded calcite scaffolds from preceramic polymers and fillers. aa6c37.

55. Stanciuc AM, Sprecher CM, Adrien J, Roiban LI, Alini M, Gremillard L, Peroglio M, Robocast zirconia-toughened alumina scaffolds: Processing, structural characterisation and interaction with human primary osteoblasts.J Eur Ceram Soc 38. $845-81$.

56. Ben-Arfa BAE, Neto AS, Palamá IE, Salvado IMM, Pullar RC, Ferreira JMF, Robocasting of ceramic glass scaffolds: Sol-gel glass,
new horizons. J Eur Ceram Soc 39: 1625-1634 (2019). https://doi. org/10.1016/j.jeurceramsoc.2018.11.019.

57. Liu X, Rahaman MN, Liu Y, Bal BS, Bonewald LF, Enhanced bone regeneration in rat calvarial defects implanted with surface-modimeed and BMP-loaded bioactive glass (13-93) scaffolds. Acta Bio-

58. Deliormanli AM, LiuX, Rahaman MN. Evaluation of borate bioactive glass scaffolds with different pore sizes in a rat subcutaneous implantation model. J Biomater Appl 28(5): 643-653, 2014.

59. Rahaman MN, Lin Y, Xiao W, Liu X, Bal B. Evaluation of Long-Term Bone Regeneration in Rat Calvarial Defects Implanted With Strong Porous Bioactive Glass (13-93) Scaffolds. In book: Biomaterials
Science: Processing, Properties, and Applications V 1 John WiScience. Processing, Propertes, and Applications V. 1, Jo1n Whcha.

60. Lin Y, Xiao W, Liu X, Bal BS, Bonewald LF, Rahaman MN, Longterm bone regeneration, mineralization and angiogenesis in rat calvarial defects implanted with strong porous bioactive glass
(13-93) scaffolds. I Non-Cryst Sol 432: 120-129 (2016). http:// dx.doi.org/10.1016/j/.jnoncrysol.2015.04.008.

61. Simon JL, Michna S, Lewis JA, Rekow ED, Thompson VP, Smay JE, Yampolsky A, Parsons JR, Ricci JL, In vivo bone response to 3D ing. J Biomed Mater Res A, 83(3): 747-58 (2007). https://doi org/10.1002/jbm.a.31329.

62. Dellinger JG, Eurell JAC, Jamison RD, Bone response to 3D periodic hydroxyapatie scaffolds with and without tallored microporosity to deliver bone morphogenelic protein 2.J Blomed Mater Res A 76(2): 366-76 (2006). DOI: 10.1002/jbm.a.30523.
63. Luo Y, Zhai D, Huan Z, Zhu H, Xia L, Chang J, Wu C. Three-Dimensional Printing of Hollow-Stuts-Packed Bloceramic Scafilds for Bone Regeneration. ACS Appl. Mater. Intriaces 7: 24377-24383 (2015). doi: 10.1021/acsami.5b08911.

64. Lin KF, He S, Song Y, Wang CM, Gao Y, Li JQ, Tang P, Wang Z, B Lei GX, Low-Temperature Additive Manufacturing of Biomimic Regeneration. ACS Appl Mater Interfaces 8(11): 6905-6916 (2016) https://doi.org/10.1021/acsami.6b00815.

65. Shao H, Liu A, KeX, Sun M, HEY, Yang X, Fu J, Zhang L, Yang G, Liu Y, XU S, Gou Z, 3D Robocasting Magnesium-doped Wollastonite/ TCP Bioceramics Scaffolds with Improved Bone Regeneration Ca2941-2051 (2017). doi: 10.1039/C7TB00217C.

Zheng J, Carlson WB, Reed JS, Dependence of compaction effi-
ciency in dry pressing on the particle size distribution. Am Ceram Soc 78(9): 2527-2533 (1995).

67. Konakawa Y, Ishizaki K, The particle size distribution for the highes relative density in a compacted body. Powder Technol 63: 241-246

68. Zheng J, Carlson WB, Reed JS, The packing density of binary powder mixtures. J Eur Ceram Soc 15: 479-483 (1995).

69. Ferreira JMF, Diz HMM, Effect of the amount of deflocculant and powder size distribution on the green properties of silicon carbide
bodies obtained by slip casting. J Hard Mater 3: 17-27 (1992).

70. Taruta S, Takusagawa N, Okada K, Otsuka N, Slip casting of alumina powder mixtures with bimodal size distribution. J Ceram Soc Japan 104: 47-50 (1996).

71. William JH, Zukoski CF, The rheology of bimodal mixtures of coltoidal particles with long-range, soft repulsions. J Colloid Interface Sci 210: 343-351 (1999).

72. Olhero S, Ferreira JM, Influence of particle size distribution on rheology and particle packing of silica-based suspensions. Powder

73. Nutz M, Furdin G, Medjahdi G, Marêché GF, Moreau M, Rheological properties of coal tar pitches containing micronic graphite powders. Carbon 35: 1023-1029 (1997).

74. Yuan J, Murray HH, The importance of crystal morphology on the viscosity of concentrated suspensions of kaolins. Appl Clay Sci 12:

75. Joseph R, McGregor WJ, Martyn MT, Tanner KE, Coates PD, Effect of hydroxyapatite morphology/surface area on the rheology and processability of hydroxyapatite filled polyethylene composites. Biomater 23(21): 4295-4302 (2002). doi:10.1016/501429612(02)00192-8

76. Feilden E, Ferraro C, Zhang Q, García-Tuñón E, D'Elia E, Giulian F, Vandeperre L, Saiz E. 3D Printing Bioinspired Ceramic Composites. Sci Rep 7 :
$017-14236-9$

77. Miranda P, Saiz E, Gryn K, Tomsia AP, Sintering and robocasting of u-tricalcium phosphate scaffolds for orthopaedic applications. Acta Biomater 2(4): 457-466 (2006). doi:10.1016/j.actbio.2006.02.004
78. Eqtesadi S, Motealleh A, Miranda P, Pajares A, Lemos A, Ferreira, JMF, Robocasting of 4555 bioactive glass scaffolds for bone
tissue engineering I Eur Ceram Soc 34(1): $107-118$ (2014). tissue engineering. J Eur Ceram Soc 3411
doi:10.1016/j.jeurceramsoc.2013.08.003

79. Zhang D, Peng E, Borayek R, Ding J. Controllable Ceramic GreenBody Configuration for Complex Ceramic Architectures with adfm. 201807082

80. He G, Hirschfeld DA, Cesarano J (n.d.), Processing and Mechanical Properties of Silicon Nitride Formed by Robocasting Aqueous
Slurries, in Ceramic Engineering and Science Proceedings, 607Slurries, in Ceramic Engineering and Science
614 (2000). doi:10.1002/9780470294635.ch72

81. Glymond D, Vandeperre $L$, Robocasting of $\mathrm{MgO}$-doped alumina using alginic acid slurries. J Am Ceram Soc 101(8): 3309-331
(2018). doi:10.1111/jace.15509

82. Schlordt T, Schwanke S, Keppner F, Fey T, Travitzky N, Greil P, Robocasting of alumina hollow filament lattice structures. J Eur Ceram Soc 33(15-16): 3243-3248 (2013). doi:10.1016/j.jeurceramsoc.2013.06.001

83. Powell J, Assabumrungrat S, Blackburn S, Design of ceramic paste formulations for co-extrusion, Powder Technol 245:21-27 (2013).

84. Bourret J, El Younsi I, Bienia M, Smith A, Geffroy PM, Marie J, Ono Y, Chartier T, Pateloup V, Micro extrusion of innovative alumina Ceram Soc 38(7): 2802-2807 (2018).

85. Faes $M$, Valkenaers $H$, Vogeler $F$, Vleugels J, Ferraris E, Extru作 28: 76-81 (2015).

86. Li W, Ghazanfari A, McMillen D, Leu MC, Hilmas GE, Watts J, Charmand extrusion. Ceram Int 44(11): 12245-12252 (2018).

87. Azzolini A, Sglavo VM, Downs JÁ, Novel method for the identificaceramic pastes. J Adv Ceram 3(1): 7-16 (2014).

88. Franks GV, Tallon C, Studart AR, Sesso ML, Leo S, Colloidal processing: enabling complex shaped ceramics with unique multiscale
structures J Am Ceram Soc 100(2): $458-490$ (2017). doi:10.1111/ jace. 14705

89. Ben-Arfa BAE, Neto AS, Miranda Salvad IM, Pullar RC, Ferreir JMF, Robocasting: Prediction of ink printability in solgel bioactive jace. 16092

90. Stickel JJ, Powell RL, Fluid mechanics and rheology of dense suspensions. Annu Rev Fluid Mech 37: 129-149 (2005). doi: 10.1146/ annurev.fluid.36.050802.122132

91. Schlordtil T, Greil P, Robocasting of Alumina Lattice Truss Structures. J Ceram Sci Technol 3(2): 81-8 (2012).

92. Smay JE, Cesarano J, Lewis JA, Colloidal Inks for Directed Assembly of 3-D Periodic Structures. Langmuir, 18(14), 5429-5437 (2002).

93. Lewis JA, Colloidal Processing of Ceramics. J Am Ceram Soc 83(10) 2341-2359 (2004). doi:10.1111/j.1151-2916.2000.tb01560.x
94. Wahl L, Lorenz M, Biggemann J, Travitzky N, Robocasting of reaction bonded silicon carbide structures, J Eur Ceram Soc 39(15)
4520-4526 (2019).

95. M'Barki A, Bocquet L, Stevenson A, Linking Rheology and Print-

96. Wolfs, R.J.M., Suiker, A.S.J. Structural failure during extrusion-based 3D printing processes. Int I Adv Manuf Technol 104, 565-584 (2019). https://doi.org/10.1007/s00170-01903844-6franks

97. Lui YS, Sow WT, Tan LP, Wu Y, Lai Y, Li H, 4D Printing and Stimuli-responsive Materials in Biomedical Applications. Acta Biomater 92: 19-36 (2019).

98. Gao B, Yang Q, Zhao X, Jin G, Ma Y, Xu F, 4D Bioprinting for Biomedical Applications. Trends Biotechnol 34(9): 746-756 (2016).

99. Liu G, Zhao Y, Wu G, Lu J, Origami and 4D printing of elastomer-derived ceramic structures. Sci Adv 4: eaat0641 (2018).

100. Tamay DG, Dursun Usal T, Alagoz AS, Yucel D, Hasirci N and Hasirci V, 3D and 4D Printing of Polymers for Tissue Engineering Apfbioe.2019.00164

101. Bargardi, F., Le Ferrand, H., Libanori, R. et al. Bio-inspired selfshaping ceramics. Nat Commun 7: 13912 (2016). https://doi org/10.1038/ncomms13912

102. Franchina G, Scanferla P, Zeffiro L, Elsayed H, Baliello A, Giacomello G, Pasetto M, Colombo P, Direct ink writing of geopoly meric inks. J Eur Ceram Soc 37: 2481-2489 (2017). 